\title{
Pemodelan dan Simulasi Sistem Proteksi Microgrid
}

\author{
Christina Tio Trisnasari, Prof. Dr. Ir. Adi Soeprijanto, M.T., Dr. Rony Seto Wibowo, S.T., MT. \\ Jurusan Teknik Elektro, Fakultas Teknologi Industri, Institut Teknologi Sepuluh Nopember (ITS) \\ Jl. Arief Rahman Hakim, Surabaya 60111 Indonesia \\ e-mail: adisup@ee.its.ac.id, ronyseto@ee.its.ac.id
}

\begin{abstract}
Abstrak-Microgrid mengintegrasi sumber energi terdistribusi untuk menyediakan sistem yang handal dan ramah lingkungan. Akibat adanya generator dan $P V$ pada semua level sistem Microgrid dan 3 konfigurasi sistem yang berbeda, yaitu hanya terhubung grid, terhubung grid dan Microgrid dan Islanding, arus gangguan pada sistem akan bervariasi (arus gangguan naik 8.2 kA ketika sistem terhubung dengan grid). Dengan koordinasi rele dan LVCB yang benar, maka sistem proteksi dapat mengamankan pembangkit dan beban. Sehingga dapat menyediakan keandalan sistem yang lebih tinggi. Sistem proteksi yang didesain dimaksudkan untuk dapat bekerja dalam 3 konfigurasi sistem yang berbeda akibat adanya grid dan sumber energy terdistribusi. Sistem proteksi yang digunakan pada tugas akhir ini dilengkapi dengan Directional Over Current Relay yang diuji menggunakan ETAP pada sebuah sistem Microgrid yang terdiri dari PV dan biomassa. Dengan menggunakan Zone Selective Interlocking ( ZSI ) tidak perlu dilakukan pengaturan ulang pada sistem proteksi yang diakibatkan adanya perubahan konfigurasi sistem.
\end{abstract}

Kata Kunci- Arus Hubung Singkat 3 fasa, Microgrid, Rele Arus Lebih Arah, Zone Selective Interlocking.

\section{PENDAHULUAN}

$\mathrm{S}_{\mathrm{e}}^{\mathrm{e}}$ emakin meningkatnya kebutuhan akan konsumsi energi listrik serta bahan bakar fosil yang terus menipis mendorong munculnya banyak variasi sumber pembangkit. Terlebih adanya desakan untuk menciptakan sumber pembangkit ramah lingkungan (green technology), menjadi salah satu faktor pendorong untuk mencari sumber energi lain selain bahan bakar fosil. Salah satu yang saat ini sedang ramai dibicarakan oleh para ilmuwan adalah pembangkit dengan konsep renewable energy yang umumnya sudah banyak dikembangkan di Negara-negara maju. Diantara pembangkit dengan konsep renewable energy tersebut, Pembangkit Listrik Tenaga Surya (PLTS) dan Pembangkit Listrik Tenaga Biomassa merupakan sumber energi alternatif yang cukup menjanjikan di Indonesia. Salah satu pemanfaatan dari tenaga surya tersebut adalah pada penggunaan Microgrid.

Microgrid merupakan salah satu contoh pola pembangkitan terdistribusi yang melingkupi berbagai macam sumber energi, dari sumber energi fosil maupun sumber energi terbarukan (renewable energy) yang memiliki sistem interkoneksi beban dan berbagai macam sumber yang terdistribusi. Microgrid juga dapat beroperasi secara paralel dengan sistem interkoneksi yang lebih besar atau beroperasi secara mandiri sehingga ketika terjadi gangguan pada Microgrid, kebutuhan energi listrik masih dapat terpenuhi dengan mengkoneksikan jaringan ke sistem utama, dalam hal ini adalah PLN. Pada Microgrid terdapat berbagai macam gangguan yang mengakibatkan terganggunya kontinuitas pasokan daya listrik. Salah satu gangguan tersebut adalah hubung singkat. Gangguan hubung singkat pada saat ini menjadi masalah yang sangat penting karena dapat menyebabkan kerusakan peralatan pada sistem bila tidak dengan segera ditangani. Sumber gangguan ini berupa gangguan dari luar, misalnya petir, dan gangguan dari dalam sistem, misalnya overload atau beban lebih.

Mencegah terjadinya gangguan dapat dilakukan dengan melindungi sistem Microgrid dengan cara meminimalkan dampak/kerusakan yang terjadi akibat gangguan. Oleh karena hal itu dibutuhkan sebuah sistem proteksi yang dapat mengisolasi daerah yang mengalami gangguan dan dapat menghindarkan kerusakan pada peralatan akibat arus hubung singkat yang mengalir pada saluran. Sistem proteksi pada penelitian ini menggunakan overcurrent relay untuk pengaman arus hubung singkat line to line dengan selective tripping yang dapat diatur berdasarkan besar dan lamanya gangguan hubung singkat yang terjadi dan directional overcurrent relay yang dapat diatur berdasarkan arah arus gangguan..

\section{TEORI PENUNJANG}

\section{A. Microgrid}

Menurut definisi EU research projects [7,8]. Microgrid merupakan meliputi sistem distribusi skala kecil, yang terdiri dari sumber energy terdistribusi, yang meliputi microturbin, fuel cells, PV dan lain sebagainya, dengan media penyimpanan energi (flywheels, kapasitor energi dan baterai) serta beban yang fleksibel. Microgrid biasanya terletak pada tegangan rendah dan harus dapat bekerja pada kondisi normal (gridconnected) dan kondisi operasi darurat (islanded), sehingga dapat meningkatkan keandalan. Selain meningkatkan keandalan, Microgrid juga ramah lingkungan.

\section{B. Gangguan Hubung Singkat}

Gangguan hubung singkat ini sendiri dapat digolongkan menjadi dua kelompok yaitu: gangguan hubung singkat simetri dan gangguan hubung singkat tak simetri (asimetri). Merupakan gangguan yang mengakibatkan tegangan dan arus yang mengalir pada setiap fasanya menjadi tidak seimbang, 
Gangguan tidak simetri akan menyebabkan mengalirnya arus tak seimbang dalam sistem sehingga untuk analisa gangguan digunakan metode komponen simetri. Gangguan ini terdiri dari : gangguan hubung singkat satu fasa ketanah, gangguan hubung singkat dua fasa dan gangguan hubung singkat dua fasa ketanah.

Gangguan simetri merupakan gangguan yang terjadi pada semua fasanya, sehingga arus maupun tegangan setiap fasanya tetap seimbang setelah gangguan terjadi. Gangguan ini terdiri dari gangguan hubung singkat tiga fasa dan gangguan hubung singkat tiga fasa ke tanah.

\section{Rele Arus Lebih (Over Current Relay)}

Rele arus lebih merupakan suatu jenis rele yang bekerja berdasarkan besarnya arus masukan, dan apabila besarnya arus masukan melebihi suatu harga tertentu yang dapat diatur (Ipp) maka rele arus lebih bekerja. Dimana Ipp merupakan arus kerja yang dinyatakan menurut gulungan sekunder dari trafo arus (CT). Bila suatu gangguan terjadi didalam daerah perlindungan rele, besarnya arus gangguan If yang juga dinyatakan terhadap gulungan sekunder CT juga. Rele akan bekerja apabila memenuhi keadaan sebagai berikut:

If $>$ Ipp rele bekerja (trip)

If $<$ Ipp tidak bekerja (blok).

Setting rele arus lebih tidak boleh bekerja pada saat beban maksimum. Arus setting harus lebih besar dari arus beban maksimum. Menurut Standart British BS 142- 1983 batas penyetelan antara nominal 1,05 - 1,3 Iset. Mengacu pada standart tersebut, pada tugas akhir ini lebih amannya menggunakan konstanta 1,05 Isett.

Pada penyetelan rele arus lebih juga harus memperhatikan batas maksimum setting, dimana

$$
\mathrm{I}_{\text {set }} \leq 0.8 \mathrm{Isc} \mathrm{LL} \text {. }
$$

Isc LL merupakan arus hubung singkat 2 phasa dengan pembangkitan minimum yang terjadi diujung saluran seksi berikutnya. Besar arus ini diperoleh dari arus hubung singkat 3 phasa pada pembangkitan minimum dikalikan 0,866.

2.1 Rele Arus Lebih Waktu Seketika (instant)

Rele ini bekerja seketika (tanpa waktu tunda) ketika arus yang mengalir melebihi nilai setting, rele akan bekerja dalam waktu beberapa mili detik. Rele ini jarang berdiri sendiri tetapi umumnya dikombinasikan dengan rele arus lebih dengan karakteristik yang lain.

2.2 Rele Arus Lebih Waktu Terbalik (inverse)

Rele ini akan bekerja dengan waktu tunda yang tergantung dari besarnya arus secara terbalik (inverse time), makin besar arus makin kecil waktu tundanya. Karakteristik ini bermacammacam dan setiap pabrik dapat membuat karakteristik yang berbeda-beda, karakteristik waktunya dapat dibedakan dalam beberapa kelompok:

- Normal inverse

- Very inverse

- Extremely inverse

- Long inverse

Adapun karakteristik operasi rele invers adalah sebagai berikut:
1. Berdasarkan standard ANSI kurva IEEE

$$
t_{d}(I)=\left[\frac{A}{\left(\frac{I}{U_{S}}\right)^{P}-1}+B\right] \times \frac{T}{\beta}
$$

Tabel 1

Konstansta Kurva IEEE

\begin{tabular}{lllll}
\hline \hline Characteristic curve & $\boldsymbol{A}$ & $\boldsymbol{B}$ & $\boldsymbol{P}$ & $\boldsymbol{B}$ \\
\hline IEEE Moderately Inverse & 0.010 & 0.023 & 0.02 & 0.24 \\
& & & & 1 \\
IEEE Very Inverse & 3.922 & 0.098 & 2 & 0.13 \\
& & & & 8 \\
IEEE Extremely Inverse & 5.64 & 0.0243 & 2 & 0.08 \\
& & & & 1 \\
\hline \hline
\end{tabular}

2. Berdasar Standar IEC [2]

Karakteristik operasi rele invers:

a. Standart inverse:

$$
\mathrm{t}=\frac{0,14}{\mathrm{I}^{0,02}-1} \mathrm{~s}
$$

b. Very inverse

$$
\mathrm{t}=\frac{13,5}{\mathrm{I}-1} \mathrm{~s}
$$

c. Extremly Inverse

$$
\mathrm{t}=\frac{80}{\left(\mathrm{I}^{2}-1\right)} \mathrm{s}
$$

d. Long Time Inverse

$$
\mathrm{t}=\frac{120}{(\mathrm{I}-1)} \mathrm{s}
$$

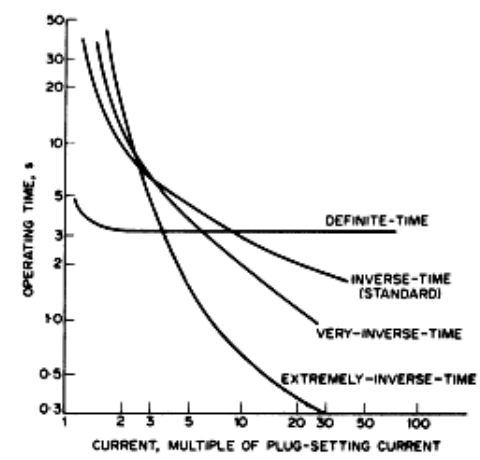

Gambar. 1. Karakteristik Operasi Rele Arus Lebih Inverse.

\section{Rele Arus Lebih Arah (Directional Over Current Relay)}

Rele arus lebih arah merupakan penggabungan rele arus lebih dan rele arah. Rele ini hanya bekerja satu arah (sesuai arah yang ditentukan), yaitu forward atau reverse dan tidak akan bekerja apabila arah gangguan berkebalikan dengan arah kerja rele. Rele ini digunakan untuk mengamankan sistem dari arus gangguan yang dapat bersirkulasi pada kedua arah ( reverse dan forward ) pada peralatan sistem, yaitu ketika sistem merupakan sistem mesh atau ring dan ketika sistem memiliki sumber lebih dari satu. 


\section{PERANCANGAN SISTEM}

Dalam simulasi koordinasi proteksi Microgrid pada tugas akhir ini menggunakan sistem Contunion Microgrid yang digunakan di Belanda dengan sistem Microgrid tiga fasa bertegangan $400 \mathrm{~V}, 50 \mathrm{~Hz}$ yang dikoneksikan ke sistem distribusi $20 \mathrm{kV}$ melalui trafo $400 \mathrm{kVA}$ [1]. Pembangkit utama pada sistem ini berupa Grid yang tersambung dengan DG, yaitu empat PV Array dan empat pembangkit biomass yang tersebar di Bus 30, 31, 32 dan 33.

\section{A. Perancangan Perubahan Topologi Jaringan}

Jaringan distribusi dengan distributed energy resources memiliki karakteristik perubahan konfigurasi yang disebabkan adanya perubahan kondisi jaringan. Hal tersebut menyebabkan beberapa pengaruh terhadap koordinasi proteksi jaringan tersebut. Skema kondisi perubahan topologi jaringan yang dapat terjadi pada simulasi ini diantaranya adalah sebagai berikut:

1. Jaringan Terhubung Grid dan Microgrid off

Pada kondisi ini, jaringan mendapat sumber dari Grid saja. Gambar 2 menampilkan topologi jaringan tersebut.

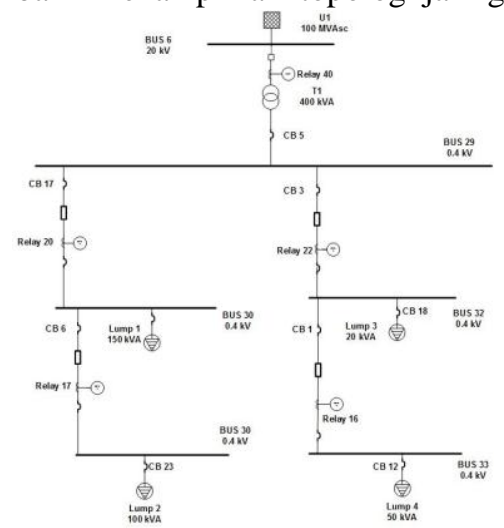

Gambar. 2. Jaringan Terhubung Grid Saja.

2. Jaringan Tidak Terhubung Grid (Islanding)

Pada kondisi ini, jaringan mendapat sumber hanya dari Microgrid, Gambar 3 menampilkan topologi jaringan tersebut.

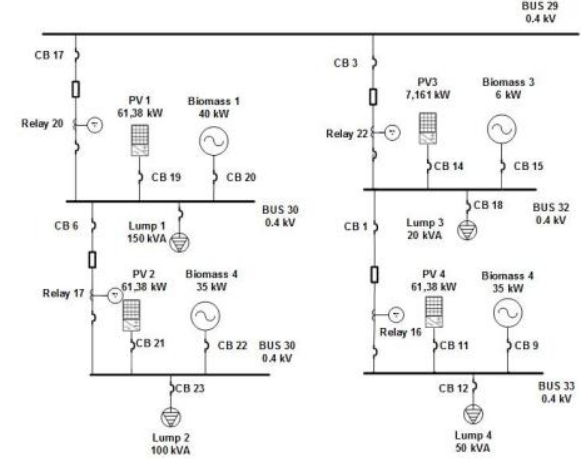

Gambar. 3. Jaringan Tidak Terhubung Grid (Islanding)

\section{Jaringan Terhubung Grid dan Microgrid on}

Pada kondisi ini, jaringan mendapat sumber dari Grid dan Microgrid, jika tejadi gangguan pada salah satu bus diantara Grid dan Microgrid, maka perlu diperhatikan arus kontribusi yang menuju bus tersebut.

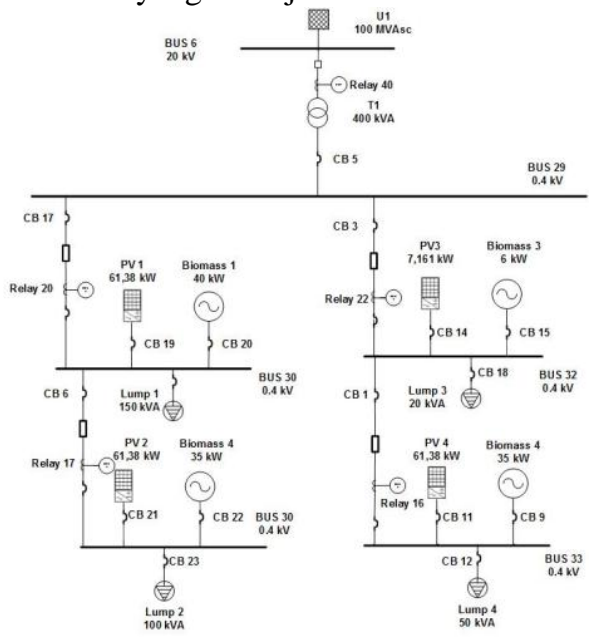

Gambar. 4. Jaringan Terhubung Grid dan Microgrid.

\section{HASIL SIMULASI DAN ANALISA}

\section{A. Analisa Hubung Singkat}

Dalam menghitung arus hubung singkat pada jaringan distribusi radial, dilakukan dengan menggunakan software simulasi yaitu ETAP. Simulasi hubung singkat minimal dan maksimal dilakukan dengan mempertimbangkan 5 kondisi yang berbeda tersebut yaitu:

a. Kondisi Hanya Terhubung Grid ( kondisi 1)

b. Kondisi Islanding ( kondisi 2 )

c. Kondisi Terhubung Grid dan Microgrid ( kondisi 3 )

Hasil simulasi hubung singkat ditampilkan pada Tabel 2 hingga Tabel 4.4 dibawah ini.

Tabel 2

Arus hubung singkat tiap bus ketika kondisi hanya terhubung dengan Grid

\begin{tabular}{|c|c|c|c|c|}
\hline No & Bus & $\begin{array}{l}\text { Tegangan } \\
(\mathrm{KV})\end{array}$ & Isc $\min (\mathrm{kA})$ & Isc $\max (\mathrm{kA})$ \\
\hline 1 & Bus 29 & 0.4 & 6.99 & 8.72 \\
\hline 2 & Bus 30 & 0.4 & 4.05 & 5.23 \\
\hline 3 & Bus 31 & 0.4 & 3.15 & 4.04 \\
\hline 4 & Bus 32 & 0.4 & 4.05 & 4.91 \\
\hline 5 & Bus 33 & 0.4 & 2.5 & 3.07 \\
\hline
\end{tabular}

Tabel 3

Arus hubung singkat tiap bus ketika kondisi Islanding

\begin{tabular}{|c|c|c|c|c|}
\hline No & Bus & $\begin{array}{l}\text { Tegangan } \\
(\mathrm{KV})\end{array}$ & Isc min (kA) & Isc max (kA) \\
\hline 1 & Bus 29 & 0.4 & 1.09 & 1.84 \\
\hline 2 & Bus 30 & 0.4 & 1.15 & 2.01 \\
\hline 3 & Bus 31 & 0.4 & 1.12 & 1.94 \\
\hline 4 & Bus 32 & 0.4 & 1.04 & 1.71 \\
\hline 5 & Bus 33 & 0.4 & 0.998 & 1.59 \\
\hline
\end{tabular}

Tabel 4

Arus hubung singkat tiap bus ketika kondisi terhubung dengan Grid dan Microgrid

\begin{tabular}{|c|c|c|c|c|}
\hline No & Bus & $\begin{array}{l}\text { Tegangan } \\
(\mathrm{KV})\end{array}$ & Isc $\min (\mathrm{kA})$ & Isc max (kA) \\
\hline 1 & Bus 29 & 0.4 & 7.73 & 9.56 \\
\hline 2 & Bus 30 & 0.4 & 4.84 & 6.19 \\
\hline
\end{tabular}




\begin{tabular}{llllr}
\hline \hline 3 & Bus 31 & 0.4 & 3.77 & 4.79 \\
4 & Bus 32 & 0.4 & 4.47 & 5.4 \\
5 & Bus 33 & 0.4 & 2.94 & 3.54 \\
\hline \hline
\end{tabular}

Dari Tabel $2-4$ dapat dilihat bahwa arus hubung singkat tiap bus dengan beberapa kondisi menghasilkan nilai yang berbeda. Maka dari itu, dalam analisa selanjutnya akan dibahas pengaruh perbedaan tersebut terhadap koordinasi proteksi. Dalam hasil simulasi dapat dilihat bahwa status Microgrid yang terhubung dengan jaringan grid mempengaruhi besar arus gangguan pada tiap bus.

\section{B. Penerapan Zone Selective Interlock Dalam Koordinasi Proteksi Microgrid}

Perbedaan level tegangan pada setiap konfigurasi, terutama pada saat kondisi grid yang terhubung dan tidak terhubung dengan sistem, membuat setting tap rele dan LVCB pada setiap kondisi menjadi berbeda. Padahal, pada kenyataannya, perubahan setting rele dan LVCB hanya dilakukan pada saat maintenance. Ada berbagai cara untuk membuat agar setting tap rele dan LVCB tidak berubah, yaitu dengan penambahan ZSI ( Zone Selective Interlock) atau dengan penambahan Fault Current Limiter pada PCC agar arus kontribusi dari grid jadi tidak terlalu besar. Pada tugas akhir ini digunakan ZSI untuk mengatur time delay peralatan pengaman pada saat terjadi gangguan.

Berikut hasil simulasi dari sistem koordinasi proteksi Microgrid dengan menggunakan ZSI ketika terjadi gangguan pada bus 30 .

\section{Kondisi Islanding}

Ketika terjadi gangguan 3 fasa pada Bus 30, arus gangguan pada bus 30 sebesar 2,9 kA. CB 6, CB 17, CB 19, CB 20 dan CB 13 merasakan adanya gangguan dan mengirim sinyal ke ZSI. Lalu ZSI akan memerintahkan keempat CB tersebut untuk membuka pada 0,1 sekon, dan melakukan blocking signal pada $\mathrm{CB}$ dan relay lainnya.

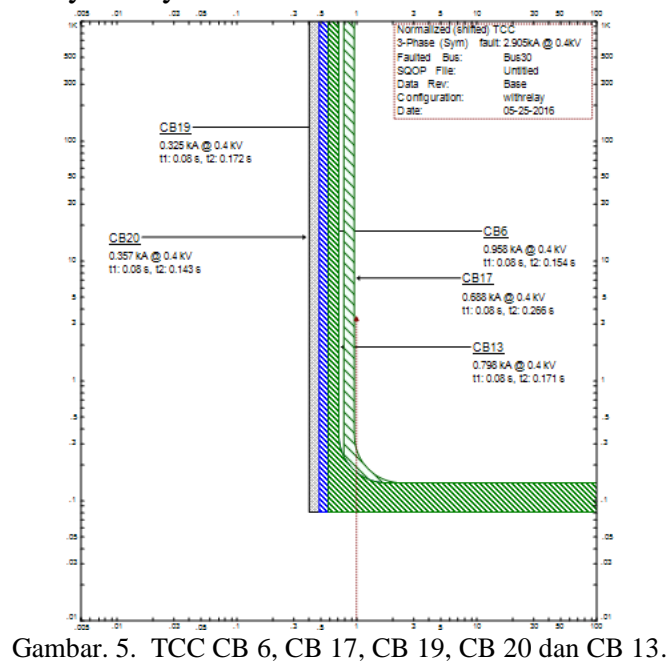

Saat CB 6,CB 17, CB 19, CB 20 dan CB 13 gagal mengamankan gangguan yang terjadi, Relay 17 ( DOCR ) akan mulai bekerja sesuai dengan setting koordinasi proteksinya, seperti yang ditunjukkan pada Gambar 6.

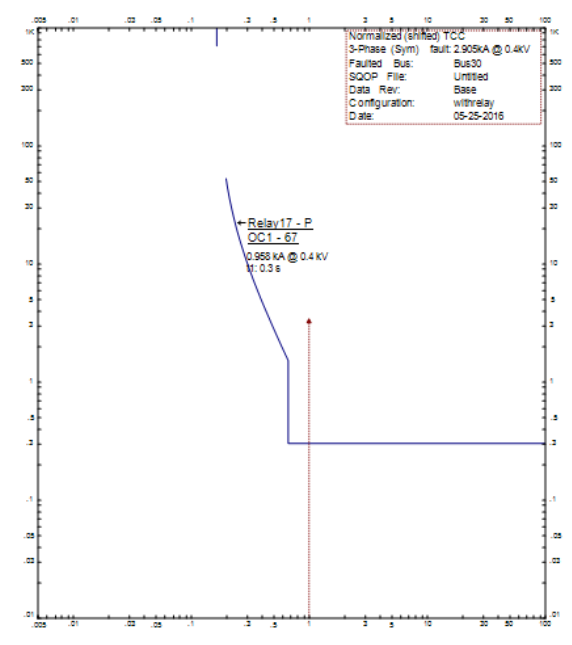

Gambar. 6. TCC Relay 17.

\section{Kondisi Grid Only}

Ketika terjadi gangguan 3 fasa pada Bus 30, arus gangguan pada bus 30 sebesar 6,02 kA. CB 17 dan CB 13 merasakan adanya gangguan dan mengirim sinyal ke ZSI. Lalu ZSI akan memerintahkan kedua CB tersebut untuk membuka pada 0,1 sekon, dan melakukan blocking signal pada CB dan relay lainnya.

Saat CB 17 dan CB 13 gagal mengamankan gangguan yang terjadi, CB 5 akan bekerja sebagai back up, dan apabila CB 5 gagal mengamankan, Relay 40 akan bekerja seperti yang ditunjukkan pada Gambar 8.
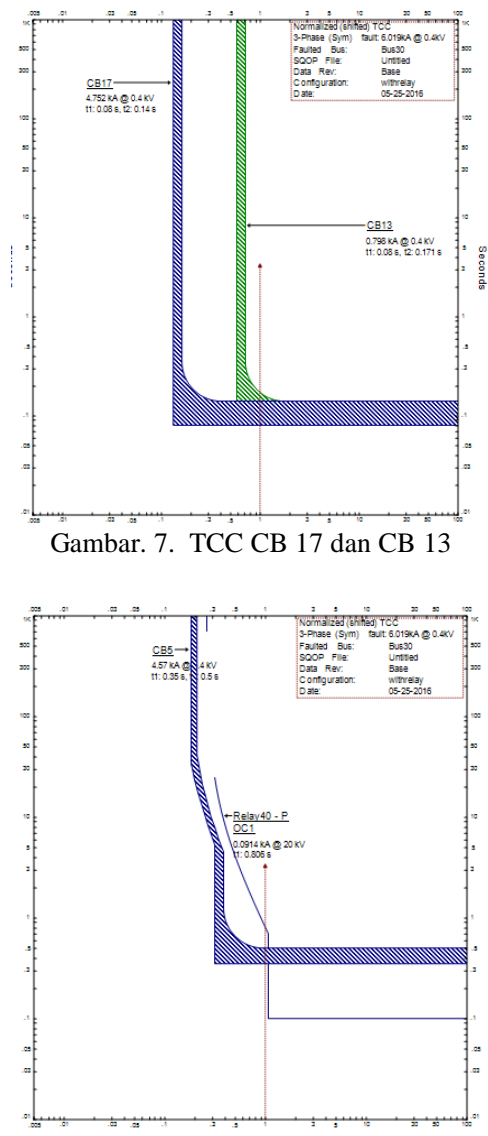

Gambar. 8. TCC Relay 40 dan CB 5. 


\section{Kondisi Terhubung Grid dan Microgrid}

Ketika terjadi gangguan 3 fasa pada Bus 30, arus gangguan pada bus 30 sebesar 6,95 kA. CB 6,CB 17, CB 19, CB 20 dan CB 13 merasakan adanya gangguan dan mengirim sinyal ke ZSI. Lalu ZSI akan memerintahkan keempat CB tersebut untuk membuka pada 0,1 detik, dan melakukan blocking signal pada $\mathrm{CB}$ dan relay lainnya.

Saat keempat CB tersebut gagal mengamankan gangguan yang terjadi, CB 5 dan Relay 17 akan bekerja sebagai back up, dan apabila CB 5 gagal mengamankan, Relay 40 akan bekerja seperti yang ditunjukkan pada Gambar 11 dan Gambar 12.

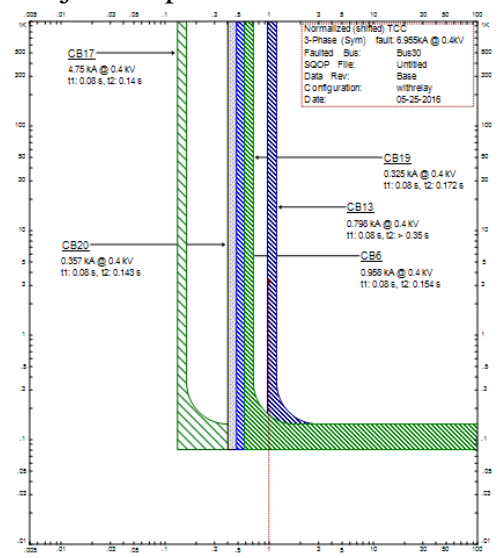

Gambar. 9. TCC CB 6, CB 17, CB 19, CB 20 dan CB 13.

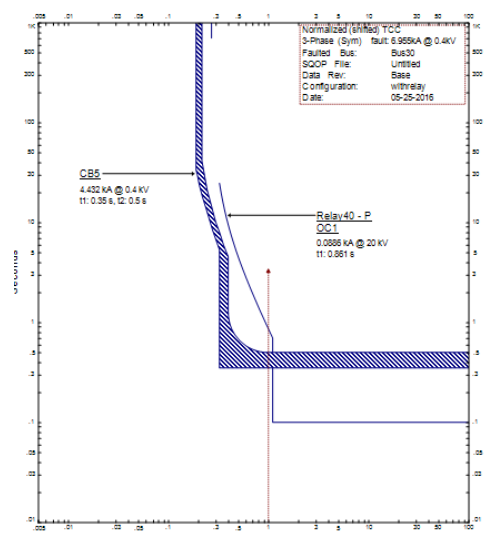

Gambar. 10. TCC Relay 40 dan CB 5.

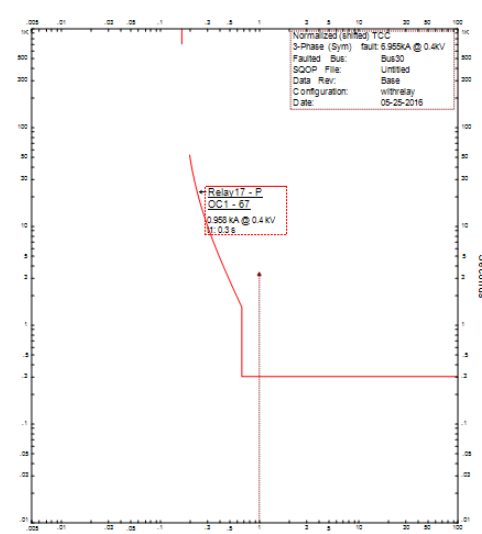

Gambar. 11. TCC Relay 17.

\section{KESIMPULAN/RINGKASAN}

Berdasarkan hasil analisa koordinasi sistem proteksi Microgrid, Terjadi peningkatan arus hubung singkat yang cukup signifikan ketika sistem Microgrid dihubungkan dengan grid, dimana arus hubung singkat 3 fasa naik 8,2 kA. Agar sistem proteksi dapat bekerja dalam tiga konfigurasi yang berbeda, yaitu saat hanya terhubung Microgrid saja (Islanding), saat terhubung grid saja dan ketika terhubung keduanya, digunakan ZSI ( Zone Selective Interlocking ) agar resetting LVCB dan rele tidak perlu dilakukan ketika konfigurasi berubah. ZSI akan mengamankan gangguan dengan membuat peralatan pengaman yang berada pada zona gangguan bekerja 0,1 detik dan ketika pengaman tersebut gagal, maka pengaman berikutnya yang bekerja sebagai back up akan bekerja sesuai setting proteksi yang dilakukan.

\section{DAFTAR PUSTAKA}

[1] R Wahyudi, Ir, Diktat Kuliah Sistem Pengaman Tenaga Listrik, 2008

[2] Ontoseno Penangsang. Prof, Diktat Kuliah Analisis Sistem Tenaga 2, 2008

[3] Hebatallah Mohamed Sharaf, H.H. Zeineldin, Doaa Khalil Ibrahim, Essam El Din Abo El Zahab. Protection Coordination of Directional Overcurrent Relays Considering Fault Current Direction. IEEE PES Innovative Smart Grid Technologies Europe, October 2014. 